\title{
Rural Victimization and Policing during the COVID-19 Pandemic
}

\section{J. Andrew Hansen ${ }^{1}$ • Gabrielle L. Lory ${ }^{2}$}

Received: 18 May 2020 / Accepted: 1 July 2020 /

Published online: 17 July 2020

(C) Southern Criminal Justice Association 2020

\begin{abstract}
Rural criminal justice organizations have been overlooked by researchers and underfunded in the United States, exacerbating problems caused by the coronavirus pandemic. Access to victims' services has been a longstanding issue in rural communities, but has become more difficult due to stay-at-home orders and changes in daily activities. Requirements such as social distancing, necessitated by COVID-19, have increased the risk of domestic violence and rural service providers are less prepared than those in more populated areas. Rural law enforcement agencies, on the other hand, have traditionally operated with smaller budgets and staffs - conditions that have complicated the response to the unprecedented event. Many of the recommended practices for policing during a pandemic have been more applicable to larger urban and suburban departments with more resources and officers extended across many units. The strain on rural victims' services and law enforcement has been felt only a few months into the coronavirus pandemic, while the long-term effects are not yet known.
\end{abstract}

Keywords COVID-19 · Law Enforcement · Pandemic $\cdot$ Policing $\cdot$ Rural $\cdot$ Victimization

"Rural" is a term familiar to the general public that has been largely overlooked by criminologists (Hollis and Hankhouse, 2019; Weisheit, Wells, and Falcone, 1994; Weisheit, Wells, and Falcone, 1995). The amount of attention devoted to rural crime and criminal justice systems has been disproportionate to the amount of rurality in the

J. Andrew Hansen

jahansen@wcu.edu

1 Department of Criminology and Criminal Justice, Western Carolina University, Cullowhee, NC, USA

2 Department of Sociology and Anthropology, West Virginia University, Morgantown, WV, USA 
United States, where an estimated $19.3 \%$ of the population resides in rural communities, which comprise $97 \%$ of the total land area. ${ }^{1}$ Official neglect of rural criminal justice organizations in the U.S., and the individuals who work for and rely upon them, has created historical problems with respect to rural victimization and law enforcement that have been amplified during the coronavirus pandemic. Concerns over reduced access to victims' services in rural communities have been intensified as daily routines have shifted in response to stay-at-home orders, placing rural residents at increased risk of domestic violence (DV).

Rural victims' services providers have been historically underfunded and were illequipped for the increased demand caused by the stay-at-home orders. The aforementioned programs can only effectively help when victims are capable of accessing the resources and the current pandemic has made that virtually impossible by forcing abusers into victims' daily routines. These conditions have created unique complications in responding to rural victimization during the coronavirus pandemic. ${ }^{2}$ Police in the $\mathrm{U}$. S. were also largely unprepared for COVID-19 (Moir, 2020; Oliver, 2020), but rural law enforcement (RLE) agencies tend to be smaller in size, with fewer policies, and lower budgets than their urban and suburban counterparts (National Police Foundation, 2020; Weisheit et al., 1994, 1995). On the other hand, small towns and rural areas exhibit distinct cultural norms that dictate a style of policing characterized by service- and prevention-oriented officers (Johnson and Rhodes, 2008; Meagher, 1985), and informal remedies to community problems (Falcone, Wells, and Weisheit, 2002; Wooff, 2015, 2017), which have been appropriate for the law enforcement response to COVID-19.

\section{Rural Victimization and COVID-19}

Amid the current pandemic, the whole world has been subjected to an entire battery of regulations meant to protect our society. While social distancing and self-quarantining are the best ways to protect the general population from the coronavirus, this new normal has led to a striking rise in the hidden public health emergency, domestic violence. Data continues to emerge that shows DV increases anytime families spend more time together, such as holidays or whenever children are not in school. ${ }^{3}$ While these spikes in violence already concern the criminal justice system, the conditions created by the pandemic spark panic within victims and law enforcement alike.

\footnotetext{
${ }^{1}$ Using a definition of rural determined by population density, land-use characteristics, and distance to urban areas that is updated for counties each decade (U.S. Census Bureau, 2016). In fact, the U.S. Census Bureau defines rural by first defining urban areas, which encompass urbanized areas (residential population over 50,000 people) and urban clusters (2500 to 49,000 residents), "after defining individual urban areas, rural is what is left" (Ratcliffe, Burd, Holder, and Fields, 2016, p. 1). The U.S. Department of Agriculture (2019), alternatively, measures urban and rural areas with a 9-category scale that begins with populations of 2500 to 19,999 residents adjacent to a metro area and includes 3 other categories with lower population thresholds.

${ }^{2}$ Although jails and corrections are beyond the scope of this article, it is important to note that the majority of jails in the U.S. are located in rural areas, operated by sheriffs, and commonly face similar difficulties with respect to budgetary and staffing shortfalls (Weisheit et al., 1995).

${ }^{3}$ Studies of police incident reports, domestic violence reports, hotline usage, and an analysis of emergency calls have all been conducted to confirm the increased likelihood of domestic violence during family gatherings (Joshi and Sorenson, 2010; Vazquez, Stohr, and Purkiss, 2005).
} 
Before the coronavirus outbreak, rural victims already faced additional boundaries to victim services compared to their urban or suburban counterparts. These barriers include the fear of breaking of strong social ties, forcing formal agencies into a typically informal setting, the stigma associated with acts of sex, and lack of transportation (Grossman, Hinkley, Kawalski, and Margrave, 2005). A cross-sectional, clinic-based survey found that the mean distance to the nearest intimate partner violence (IPV) resource was at least three times higher for rural victims than their urban counterpart. Over $25 \%$ of the women surveyed in rural areas lived over 40 miles from the closest resource, while only $1 \%$ of urban women had to travel that far for assistance. Rural women also reported higher levels of severity (i.e., physical abuse) than their urban counterparts. Finally, the survey highlighted the differing rates of IPV with the highest prevalence at $22.5 \%$ for rural and $15.5 \%$ for urban women (Peek-Asa et al., 2011). High rates of domestic violence combined with limited resources, have resulted in dangerous situations for rural victims. With many cases of domestic abuse ending fatally ( $23 \%$ of women killed are in the process of trying to leave an abusive partner), the lack of resources to rural women is a significant hurdle to a functional society (DeKeseredy and Schwartz, 2009). COVID-19 has enhanced these rural barriers and made it nearly impossible for rural victims to reach the necessary resources during an emergency.

Although there is a growing number of articles pertaining to victim services, most studies conducted have been focused in urban settings. This pattern of examination has resulted in criminal and social policies gearing towards the benefit of urban populations despite similar rates of crime occurring in rural communities (Peek-Asa et al., 2011; Weisheit et al., 1995). This bias in policy often unwittingly supports the misconception that crime is rare in rural communities; therefore, they need fewer resources to handle crime. This perpetuation of this fallacy ensures that victims burdened with the realities of rural life are met with even more challenges to escape violence in their homes. It should be stated that victims of domestic violence, regardless of location or socioeconomic status, endure unspeakable pain and suffer both mental and physical consequences. However, the plight of the rural victim has been highlighted due to their distinct lack of adequate, accessible support; made apparent by COVID-19.

A severe lack of capital, common in most rural communities, reduces a victim service provider or program's ability to serve a community well. The absence of a wellpaid staff and a stocked resource center make the provider's job impossible. Additionally, rural programs typically cover larger geographic areas, which amplifies the risk of inconsistent treatment and limits access to those victims without personal transportation (Benson, 2016). These barriers to victims and resource providers have led to reduced reporting rates and an unsafe dependence on informal social controls (Weisheit, Falcone, and Wells, 2006).

Unfortunately, all these tragic realities have only been highlighted during the recent peaks in domestic violence witnessed after the stay-at-home orders began. As the regulations were slowly put into place, domestic violence hotlines quickly began receiving increased numbers of calls and officers were more regularly dispatched on DV calls. For example, New York State Police troopers responded to 1753 domestic violence calls in March 2020, compared to 1522 in March 2019, while the New York state DV hotline reported an $18 \%$ increase in calls from February to March 2020 (Southall, 2020). The Childhelp National Child Abuse Hotline also reported a $17 \%$ 
increase when comparing April 2019 and April 2020 (Bosman, 2020). However, those numbers quickly reduced as more victims found themselves locked in their homes with their abuser and were unable to safely contact help. Melinda Katz, the district attorney in Queens, New York, reported a 40\% decrease in domestic violence arrests during quarantine, while Safe Horizon, a New York City-based nonprofit, reported an 11\% decrease in phone calls, but increased use of their online chat service (Southall, 2020). Now, hotlines are reporting calls that are hushed and quick, due to the victim's total lack of privacy, or they report receiving calls from concerned neighbors or witnesses (Fielding, 2020). These reports have reaffirmed the fears of both scholars and victim advocates, who stated their concern about a silent wave of domestic violence as a result of social distancing early in the spread of COVID-19. Statistically, only around onehalf of DV cases get reported to the authorities and the circumstances inflicted by the coronavirus only reduce those chances (Reaves, 2017).

Victims often fear their abusers too much to report domestic violence, but for rural victims, these fears are specially compounded by the realities of a rural lifestyle. For instance, if the wife of a farmer were to report her abusive partner, she would have to ensure phone access (i.e., landline or cell service) to make the call and transportation off the farm (i.e., a car not controlled by the abuser). If she did not have access to such a vehicle, she would then be dependent on the response times of police and medical emergency teams, and the road conditions on the day of the reported incident. In rural areas, it can take as long as an hour for emergency services to reach a residence after dispatch, and rural victims are painfully aware of that reality. ${ }^{4}$ Lastly, the economic conditions of rural life can often lead to a lack of restraining orders against abusers simply because they have to tend animals or farm the land that the victim inhabits. The regulations necessary to slow the spread of COVID-19 further enhance the difficulty of the experience described above. For example, commonly cited abuse tactics of domestic abusers are the isolation of their victims, imposing restrictions, and constant surveillance. Social distancing, mandated closures and travel restrictions have made all these abuse strategies easier than ever before while making accessing resources nearly impossible (Campbell, 2020).

In addition to individual factors, unemployment, economic strain, and gun ownership have all been found to increase the likelihood of violence within the home (Kivisto, Magee, Phalen, and Ray, 2019). The coronavirus has caused historically high unemployment claims, ${ }^{5}$ severe hits to the stock market, and gun sales have sky-rocketed since March. ${ }^{6}$ The effects of the inadequate victim resources, rural lifestyle, forced social isolation, and increased contact with family members have been previously wellresearched and documented. While data on the rates of domestic violence during COVID-19 has not yet been collected, it can be assumed that DV rates have increased due to the COVID-19 regulations and historical patterns of abuse. This article aims to highlight the heightened susceptibility of rural communities to domestic violence, specifically during a global pandemic. Unfortunately, problems facing rural

\footnotetext{
${ }^{4}$ Studies have found that victims are at an increased likelihood of violence and death during "separation" or anytime they choose to seek help (DeKeseredy, Dragiewicz, and Schwartz, 2017).

${ }^{5}$ The U.S. government has reported the unemployment rate at $14.7 \%$, with over 20 million jobs lost in April 2020 due to the coronavirus pandemic (U.S. Bureau of Labor Statistics, 2020).

${ }^{6}$ Collins \& Yaffe-Bellany (2020) reported March 2020 was the second-busiest month ever for gun sales in an analysis of sales over the last twenty years.
} 
communities have historically been met with a lack of urgency by government officials and they are often left to tend to the issue internally. However, the current public health emergency has brought attention to the severe lack of infrastructure available to victims of domestic violence; which will hopefully draw the concern of legislators and funding opportunities.

Regrettably, no level of government was prepared for the 'perfect storm' of circumstances created for abusers by the public health measures necessary to slow the spread of COVID-19. In response, officials have relied upon the victim services that already existed within their local infrastructure. Meaning, despite the increased likelihood of abuse during isolation and increasing reports of domestic violence during this pandemic, no additional resources have been made available to victims. No major relief programs have been created specifically for DV victims during the COVID-19 crisis; officials are just encouraging the use of previously available hotlines and apps. Essentially, a victim must have full access to the internet or unfettered, private access to an active phone line in order to report a crime against them during this pandemic. Even these seemingly simple requirements can quickly exclude vast numbers of domestic violence victims from accessing help in an emergency or reaching the appropriate resources. ${ }^{7}$ Fortunately, some areas with existing programs have implemented chat services online so that victims can silently contact help online, as well as telehealth appointments and virtual legal aid (Fielding, 2020). Victims living in areas with no pre-existing programs now have even less access to help due to the increased demand and adaptations required to maintain social distancing and a functional resource center.

Before the coronavirus took over our news cycles and regulated our lives, family violence was already ravaging our communities. Agencies were already operating under the pressure of a growing workload and dwindling resources, and they are now facing the greatest demand for victim resources in recent history. In order to reach victims that have been cut off from their communities, resource providers must expand local partnerships and operate smoothly with various agencies. Alternative forms of detecting violence in the home must be utilized, such as the use of postal workers or garbage collectors to perform welfare checks and report signs of domestic abuse to local authorities. Law enforcement must also be readily prepared to combat the challenges faced by rural victims and address domestic violence more effectively, especially during peak times such as during COVID-19.

\section{RLE Staffing and COVID-19}

There is no commonly agreed-upon definition of the term "rural law enforcement" (Weisheit et al., 1995), and many studies have included no operational definitions whatsoever (International Association of Chiefs of Police, 2018; National Police Foundation, 2020). Definitions of RLE existing in the policing literature have been primarily based on residential populations of jurisdictions they served as estimated by census data (Falcone et al., 2002; Payne, Berg, and Sun, 2005; Saunders et al., 2020).

\footnotetext{
${ }^{7}$ Nearly one-quarter of rural residents claimed to have trouble with internet access in their area and consistently lower access to phone service (Anderson, 2018).
} 
Indeed, the terms "rural law enforcement agency" and "small law enforcement agency" have been nearly synonymous in the policing literature (International Association of Chiefs of Police, 2018; Saunders et al., 2016), and small size has been considered to be a defining characteristic of RLE organizations ${ }^{8}$ (Falcone et al., 2002). Stereotypical depictions have been evoked, such as the Sheriff of Mayberry - a community of 2000 in rural North Carolina, fictionalized in The Andy Griffith Show (Liederbach and Frank, 2003; Weisheit et al., 1995). In the U.S., approximately 12,261 police departments and 3012 sheriff's offices existed in 2016, the majority of which employed few officers and served small populations (Brooks, 2019; Hyland and Davis, 2019). Among police departments, an estimated $38.7 \%(n=4743)$ policed fewer than 2500 residents, while $94.0 \%$ ( $n=11,552)$ had jurisdictions with less than 50,000 people (Hyland and Davis, 2019). In 2013, 69.7\% ( $n=2099)$ of sheriff's offices served populations smaller than 50,000 persons (Brooks, 2019). Jurisdictional populations have been strongly correlated with staff sizes, so small agencies have been the norm in the U.S., where over three-quarters of police $(75.1 \%)$ and one-half of sheriff's $(55.5 \%)$ organizations had fewer than 25 officers (Brooks, 2019; Hyland and Davis, 2019).

Difficulties for RLE agencies that existed before the coronavirus, such as staffing shortages (National Police Foundation, 2020), and large geographic jurisdictions (International Association of Chiefs of Police, 2018), have been compounded by the pandemic (Philips, 2020). The ability to adequately serve a population, if a sizeable portion of officers become ill, is a particularly salient concern among RLE, where officers were already spread thin (Philips, 2020; Robson, 2020). The Detroit Police Department has roughly 2800 employees, over 1000 of whom have been quarantined (Eligon and MacFarquhar, 2020), and while losing one-third of employees has required back-to-back shifts and personnel transfers between units in this large department (Bleiberg and Williams, 2020), this would be particularly devastating for RLE agencies. Case in point, a rural police department with 12 officers that serves a town of 6000 in Michigan had 3 officers who tested positive for COVID-19 and another 3 quarantined (Philips, 2020). Even if services are not diminished, response times, which tended to be longer in rural areas before the pandemic (Yarwood and Cozens, 2004), could be further extended.

A recommended best practice has been to use a "platoon" or team-based concept, where the same officers and supervisors always work together to avoid crosscontamination (National Fraternal Order of Police, 2020). The Tempe Police Department, a large agency with hundreds of officers, has implemented this strategy for their three teams of investigators (Moir, 2020). A similar approach is keeping one-half of officers at home to fill-in when those in the working group get sick (National Fraternal Order of Police, 2020). Such strategies are unlikely to work in rural agencies already struggling to fill patrol shifts. Partnerships with community members, including other law enforcement organizations, have been vital for RLE in the past (National Police Foundation, 2020), so it comes as little surprise that law enforcement has been encouraged to partner when responding to a pandemic (Luna, Brito, and Sanberg, 2007). Unfortunately, researchers have found that problem-solving partnerships tend to become more common as jurisdictional population size increases in the U.S. For

\footnotetext{
${ }^{8}$ Even though small-towns and sparsely-populated areas in the U.S. are simultaneously policed by large state and federal agencies with thousands of employees headquartered in metropolitan, capital areas.
} 
instance, Reaves (2015) reported that $21 \%$ of police departments serving fewer than 2500 residents had established local problem-solving partnerships, while participation rose to $86 \%$ among agencies with 1000,000 or more people in their jurisdictions. If agencies collaborate with nearby law enforcement organizations, a remaining concern is that multiple jurisdictions could be affected by COVID-19 if regional dispatch centers experienced staffing shortages (Robson, 2020).

\section{RLE Guidance and COVID-19}

RLE agencies began the coronavirus pandemic from a particularly disadvantaged position due to an overall lack of guidance and information specific to the rural context. Although few, if any, agencies in the U.S. had anticipated a pandemic, some were equipped with broader disaster plans (Moir, 2020). Unfortunately, RLE organizations have been less likely to maintain emergency and disaster plans (Call, 2010), and have been found to be lacking detailed, written policies (Weisheit et al., 1995). When responding to a pandemic, law enforcement agencies have been encouraged to work with local public health departments (Luna et al., 2007), but rural communities often have none, or they lack the capacity and resources of larger areas (Office of Rural Health Policy, 2002). Thus, agency leaders have been forced to look elsewhere for advice.

It has been observed for decades that rural agencies have been underrepresented in policing research (National Police Foundation, 2020; Reiss, 1992; Weisheit et al., 1995), and the lack of pandemic planning and response literature specifically for RLE has created difficulties in planning on the fly for an unforeseen pandemic. For instance, Police Executive Research Forum (PERF) authored, Police Planning for an Influenza Pandemic: Case Studies and Recommendations, a 100-plus page report with cases studies of 4 urban and suburban police departments that employed between 250 and over 5000 sworn officers (Luna et al., 2007). However, the case studies were not representative of law enforcement in the U.S., where only $1.6 \%$ of police departments and $4.4 \%$ of sheriff's offices employ 250 or more sworn employees. In the following years, PERF convened advisory groups and authored a series of three reports on responding to public health emergencies specific to influenza planning (Brito, Luna, and Sanberg, 2009a), communications (Brito, Luna, and Sanberg, 2009b), and occupational health (Sanberg, Brito, Luna, and McFadden, 2010). Although some of the information has been applicable to all agencies, there was almost no mention of rural agencies specifically, and only one representative from RLE sat on an advisory board (Brito et al., 2009a, 2009b; Luna et al., 2007; Sanberg et al., 2010).

Some of the suggestions in the PERF reports were not directly applicable to RLE agencies. For instance, agencies have been advised to identify non-essential activities that can be suspended (Brito et al., 2009a; Luna et al., 2007), but RLE already had larger proportions of officers assigned to patrol functions than urban and suburban agencies (Bayley, 1994), in addition to fewer officers in specialized units (Hyland and Davis, 2019; International Association of Chiefs of Police, 2018). As a result, RLE agencies were less likely to have officers in non-essential units that resources could be transferred from if patrol or other vital areas faced staffing shortages. Agencies have also been counseled to cross-train employees on the vital functions that must be 
maintained, so resources can be shifted among units if a substantial portion of officers fall ill (Luna et al., 2007). RLE officers tend to be generalists, experienced in patrol and a variety of other tasks, whereas policing in urban areas has mostly been conducted by specialists (Falcone et al., 2002), so this suggestion appears to be directed at large agencies. The fact that generalists are commonplace in RLE agencies has its benefits though and could prove useful if a substantial portion of officers become sick.

\section{RLE Budgets and COVID-19}

Guidance specific to the rural context is not the only resource that RLE agencies have struggled to obtain during the COVID-19 pandemic. Another of the hardships confronting RLE organizations has been a lack of financial resources, as low budgets have been standard in rural areas for years (Weisheit et al., 1994; National Police Foundation, 2020). In turn, small agencies have spent far less on a per officer basis than larger organizations (Reaves, 2015), reducing the odds of having necessary equipment on-hand when the pandemic struck. A 2013 survey of law enforcement agencies across the U.S. estimated the smallest agencies, those serving populations of 2499 or fewer, allocated an average of $\$ 67,041$ per officer, roughly one-half the national average of $\$ 131,273$ (Reaves, 2015). Agencies have become more reliant on telephone and online reporting systems since the pandemic began (Bleiberg and Williams, 2020), and have been encouraged to do so, (National Fraternal Order of Police, 2020), yet researchers have found RLE agencies lacked funding to acquire new technology in the preceding years (National Police Foundation, 2020; Saunders et al., 2016). While organizations with large budgets may have a pool of discretionary funding that can be redirected to purchase PPE and technologies such as online reporting systems, smaller agencies have reduced capacity (International Association of Chiefs of Police, 2018; Saunders et al., 2016).

\section{RLE Style and COVID-19}

It has been recognized since Wilson's (1968) seminal study that environmental context drives police behavior and style, and subsequent work has extended that lesson to RLE. For instance, Liederbach \& Frank (2003) conducted systematic social observations in five rural, Ohio police departments with an average of six employees per agency and concluded, "there is evidence to suggest that the work of small- town and rural officers is somewhat shaped by the unique social and demographic climate of smaller, less urban environments" (p. 69). Tight-knit communities in rural areas have close relationships with their officers (Liederbach and Frank, 2003), who are expected to eschew arrest and use informal remedies when possible (Falcone et al., 2002; Wooff, 2015, 2017). Relatedly, RLE officers are more service- and prevention-oriented than officers in urban places who focus on law enforcement (Johnson and Rhodes, 2008; Meagher, 1985), even to the point of serving as de facto social workers in some rural areas (Marenin and Copus, 1991). The RLE agencies' way of handling community problems seems to naturally lend itself to the law enforcement response to COVID-19 in the U.S. so far. 
At the time this article was written in mid- to late-spring of 2020, law enforcement agencies in the U.S. have largely been hesitant to enforce stay-at-home orders (Bleiberg and Williams, 2020; Dewan, Swales, and Vigdor, 2020; Eligon and MacFarquhar, 2020; Philips, 2020), relying instead on voluntary compliance through informal control, which tends to be high in rural areas, to keep people from spreading the coronavirus. If the expected response to violations of stay-at-home orders becomes more punitive, rural agencies may find themselves at a disadvantage compared with urban and suburban agencies, which are more law enforcement-oriented and accustomed to using arrest as a tool. ${ }^{9}$ Another concerning prospect to monitor as the pandemic drags on is whether reduced police-community interactions, which have been necessary to reduce transmissions, begin to erode the relationships underlying community policing.

\section{Discussion and Conclusion}

Rural victims and law enforcement have been marginalized for many decades, but with the coronavirus pandemic, the chickens have come home to roost, as historical underfunding of rural criminal justice organizations, including victims' services and law enforcement, have created difficulties in responding to a shifting crime environment. Ideally, these changes would be accompanied by increased funding, and there have been some positive signs with respect to emergency law enforcement funding. It remains to be seen how victims' services and policing organizations in rural areas will fare in the long term.

Currently, domestic violence hotlines and online service providers are reporting unprecedented demand for their services as rates of COVID-19 grow and stay-at-home orders are enforced. The historical treatment of rural service providers has left them in a precarious position, with very little resources to offer regularly, let alone during times of increased need. As it stands, there is no way to know just how many individuals are being affected by an increase in domestic violence due to new social regulations. However, through statements from domestic violence hotlines, police reports, and knowledge of rurality it can be surmised that the rates of DV have increased due to COVID-19.

According to the National Fraternal Order of Police, 82 law enforcement officers had died from COVID-19 by the end of April 2020. The Officer Down Memorial Page (2020) uses a different reporting system and inclusion criteria but stated that 16 law enforcement officers had died from "duty-related illness" in the first 4 months of 2020, 15 because of COVID-19, while 17 officers had been shot and killed. Although the officer deaths from coronavirus so far have been disproportionately in large agencies, it remains unclear at the time of this writing whether rural areas will be largely spared from the pandemic, or if the wave will arrive later and ultimately impact rural areas the hardest (Miller, Becker, Grenfell, and Metcalf, 2020). Similarly, it is not knowable at this time how rural victimization will change as the pandemic continues, or to what

\footnotetext{
${ }^{9}$ Although RLE agencies may be increasingly expected to enforce stay-at-home orders with citations and arrests, they may receive more assistance from their communities than urban and suburban agencies, as it has been suggested that rural residents are more willing to participate in law enforcement functions (Payne et al., 2005).
} 
extent anecdotal increases in domestic violence are underestimates because of the dark figure of crime. It is possible this article only scratches the surface of the impact COVID-19 will have on rural victimization and law enforcement.

\section{References}

Anderson, M. (2018, September 10). For 24\% of rural Americans, high-speed internet is a major problem. Pew Research Center. Retrieved from https://www.pewresearch.org/fact-tank/2018/09/10/about-aquarter-of-rural-americans-say-access-to-high-speed-internet-is-a-major-problem/ (accessed 10 May, 2020).

Bayley, D. H. (1994). Police for the future. New York, NY: Oxford University Press.

Benson, S. R. (2016). Assisting rural domestic violence victims: The local librarian's role. Law Library Journal, 108(2), 237-250.

Bleiberg, J., \& Williams, C. (2020, March 28). 'Officers are scared out there': Coronavirus hits US police. Associated Press. Retrieved from https://apnews.com/ 069d01bafbb1f15b1f6c4a4479ab1456 (accessed 10 May, 2020).

Bosman, J. (2020, May 15). Domestic violence calls mount as restrictions linger: 'No one can leave'. New York Times. Retrieved from https:/www.nytimes.com/2020/05/15/us/ domestic-violence-coronavirus. html (accessed 25 June, 2020).

Brito, C. S., Luna, A. M., \& Sanberg, E. L. (2009a). Benchmarks for developing a law enforcement pandemic flu plan. Police executive research forum. Retrieved from https://bja.ojp.gov/sites/g/files/xyckuh186 /files/Publications/PERF_PandemicBenchmarks.pdf (accessed 10 May, 2020).

Brito, C. S., Luna, A. M., \& Sanberg, E. L. (2009b). Communication and public health emergencies: A guide for law enforcement. Police executive research forum. Retrieved from https://bja.ojp. gov/sites/g/files/xyckuh186/files/Publications/PERF_Emer_Comm. Pdf (accessed 10 May, 2020).

Brooks, C. (2019). Sheriffs' offices, 2016: Personnel. Bureau of Justice Statistics. Retrieved from https://www. bjs.gov/content/pub/pdf/sop9313.pdf (accessed 10 May, 2020).

Call, D. A. (2010). A survey of county emergency managers' response to ice storms. Journal of Homeland Security and Emergency Management, 7(2), 1-16. https://doi.org/10.2202/1547-7355.1634.

Campbell, A. M. (2020). An increasing risk of family violence during the COVID-19 pandemic: Strengthening community collaborations to save lives. Forensic Science International: Reports., 2 , 100089. https://doi.org/10.1016/j.fsir.2020.100089.

Collins, K., \& Yaffe-Bellany, D. (2020, April 2). About 2 million guns were sold in the U.S. as virus fears spread. New York Times. Retrieved from https:/www.nytimes.com/ interactive/2020/04/01 /business/coronavirus-gun-sales.html (accessed 10 May, 2020).

DeKeseredy, W. S., \& Schwartz, M. D. (2009). Dangerous exits: Escaping abusive relationships in rural America. New Brunswick, NJ: Rutgers University Press.

DeKeseredy, W. S., Dragiewicz, M., \& Schwartz, M. D. (2017). Abusive endings: Separation and divorce violence against women. Oakland, CA: University of California Press.

Dewan, S., Swales, V. \& Vigdor, N. (2020, March 22). Police tread lightly as pandemic spreads. New York Times. Retrieved from https://www.nytimes.com/2020/03/22/us/coronavirus-police.html (accessed 10 May, 2020).

Eligon, J., \& MacFarquhar (2020, April 20). Coronavirus devastates the Detroit police force, from the chief on down. New York Times. Retrieved from https:/www.nytimes.com/2020/04/20/us/coronavirus-detroitpolice.html (accessed 10 May, 2020).

Falcone, D. N., Wells, L. E., \& Weisheit, R. A. (2002). The small-town police department. Policing: An International Journal of Police Strategies \& Management, 25(2), 371-384. https://doi.org/10.1108 /13639510210429419.

Fielding, S. (2020, April 3). In quarantine with an abuser: Surge in domestic violence reports linked to coronavirus. The Guardian. Retrieved from https://www.theguardian.com/us-news/2020/apr/03 /coronavirus-quarantine-abuse-domestic-violence (accessed 10 May, 2020).

Grossman, S. F., Hinkley, S., Kawalski, A., \& Margrave, C. (2005). Rural versus urban victims of violence: The interplay of race and region. Journal of Family Violence, 20(2), 71-81. https://doi.org/10.1007 /s10896-005-3170-y.

Hollis, M. E., \& Hankhouse, S. (2019). The growth of rural criminology: Introduction to the special issue. Crime Prevention and Community Safety, 21, 177-180. https://doi.org/10.1057/s41300-019-00068-4. 
Hyland, S. S., \& Davis, E. (2019). Local police departments: 2016. Bureau of Justice Statistics. Retrieved from https://www.bjs.gov/content/pub/pdf/lpd16p.pdf (accessed 10 May, 2020).

International Association of Chiefs of Police (2018). Policing in small, rural, and tribal communities. Retrieved from https://www.theiacp.org/sites/default/files/201811/IACP_PMP_SmallTribal.pdf (accessed 10 May, 2020).

Johnson, R. R., \& Rhodes, T. N. (2008). Urban and small town comparison of citizen demand for police services. International Journal of Police Science and Management, 11(1), 27-38. https://doi.org/10.1350 /ijps.2009.11.1.107.

Joshi, M., \& Sorenson, S. B. (2010). Intimate partner violence at the scene: Incident characteristics and implications for public health surveillance. Evaluation Review, 34(2), 116-136. https://doi.org/10.1177 /0193841X09360323.

Kivisto, A. J., Magee, L., Phalen, P., \& Ray, B. (2019). Firearm ownership and domestic versus nondomestic homicide in the U.S. American Journal of Preventative Medicine, 57(3), 311-320. https://doi.org/10.1016 j.amepre.2019.04.009.

Liederbach, J., \& Frank, J. (2003). Policing Mayberry: The work routines of small-town and rural officers. American Journal of Criminal Justice, 28(1), 53-72. https://doi.org/10.1007/BF02885752.

Luna, A. M., Brito, C. S., \& Sanberg, E. A. (2007). Police planning for an influenza pandemic: Case studies and recommendations from the field. Police executive research forum. Retrieved from https://icma. org/sites/default/files/5700_.pdf (accessed 10 May, 2020).

Marenin, O., \& Copus, G. (1991). Policing rural Alaska: The village public safety officer (vpso) program. American Journal of Police, 10(4), 1-26.

Meagher, M. S. (1985). Police patrol styles: How pervasive is community variation? Journal of Police Science and Administration, 13, 36-45.

Miller, I. F., Becker, A. D., Grenfell, B. T., \& Metcalf, C. J. E. (2020). Mapping the burden of COVID-19 in the United States. medRxiv. https://doi.org/10.1101/2020.04.05.20054700.

Moir, S. (2020, April 16). Policing during a pandemic. In T. Jackman (moderator), Policing during a pandemic [virtual roundtable]. Phoenix, AZ. Retrieved from https://vimeo. com/morrisoninstitute/asupolicingduringapandemic (accessed 10 may, 2020).

National Fraternal Order of Police (2020). COVID-19 information for law enforcement. Retrieved from https://fopcovid19.org/best-practices-and-policies/ (accessed 10 May, 2020).

National Police Foundation (2020). Conversations with rural law enforcement leaders: Volume 1. Office of Community Oriented Policing Services. Retrieved from https://cops.usdoj.gov/RIC/Publications/copsw0892-pub.pdf (accessed 10 May, 2020).

Office of Rural Health Policy (2002). Rural communities and emergency preparedness. Retrieved from https:/www.ruralhealthinfo.org/assets/198-319/rural-communities-and-emergency-preparedness.pdf (accessed 10 May, 2020).

Officer Down Memorial Page (2020). Honoring officers killed in 2020. Retrieved from https://www.odmp. org/search/year/2020 (accessed 10 May, 2020).

Oliver J. (2020, April 16). Policing during a pandemic. In T. Jackman (moderator), Policing during a pandemic [Virtual roundtable]. Phoenix, AZ. Retrieved from https://vimeo. com/morrisoninstitute/asupolicingduringapandemic (accessed 10 May, 2020).

Payne, B. K., Berg, B. L., \& Sun, I. Y. (2005). Policing in small town America: Dogs, drunks, disorder, and dysfunction. Journal of Criminal Justice, 33(1), 31-41. https://doi.org/10.1016/j.jcrimjus.2004.10.006.

Peek-Asa, C., Wallis, A., Harland, K., Beyer, K., Dickey, P., \& Saftlas, A. (2011). Rural disparity in domestic violence prevalence and access to resources. Journal of Women's Health, 20(11), 1743-1749. https://doi. org/10.1089/jwh.2011.2891.

Philips, K. (2020, April 11). It would cripple us completely: Coronavirus takes toll on rural police agencies. USA Today. Retrieved from https:/www.usatoday.com/story/news/politics/2020/04/11/coronaviruspandemic-rural-police-brace-worst/2971863001/ (accessed 10 May, 2020).

Ratcliffe, M., Burd, C., Holder, K., \& Fields, A. (2016). Defining rural at the U.S. Census Bureau. U. S. Census Bureau. Retrieved from https://www.census.gov/content/dam/Census/library/publications/2016 /acs/acsgeo-1.pdf (accessed 10 May, 2020).

Reaves, B. A. (2015). Local police departments, 2013: Personnel, policies, and practices. Bureau of Justice Statistics. Retrieved from https://www.bjs.gov/content/pub/pdf/lpd13ppp.pdf (accessed 10 May, 2020).

Reaves, B. A. (2017) Police response to domestic violence, 2006-2015. Bureau of Justice Statistics. Retrieved from https:/www.bjs.gov/content/pub/pdf/prdv0615.pdf (accessed 10 May, 2020).

Reiss, A. J. (1992). Police organizations in the twentieth century. In M. Tonry \& N. Morris (Eds.), Criminal justice: A review of the research (pp. 51-97). Chicago, IL: University of Chicago Press. 
Robson, R. (2020, April 16). Policing during a pandemic. In T. Jackman (moderator), Policing during a pandemic [Virtual roundtable]. Phoenix, AZ. Retrieved from https://vimeo. com/morrisoninstitute/asupolicingduringapandemic (accessed 10 May, 2020).

Sanberg, E. L., Brito, C. S., Luna, A. M., \& McFadden, S. M. (2010). A guide to occupational health and safety for law enforcement executives. Police Executive Research Forum. Retrieved from https://bja.ojp. gov/sites/g/files/xyckuh186/files/Publications/PERF_LE_OccHealth.pdf (accessed 10 May, 2020).

Saunders, J., Cahill, M., Morral, A. R., Leuschner, K. J., Midgette, G., Hollywood, J. S., ... \& Taylor, J. (2016). Identifying the needs and challenges of criminal justice agencies in small, rural, tribal, and border areas. RAND. Retrieved from https://www.rand.org/content/dam/rand/pubs/research_ reports/RR1400/RR1479/RAND RR1479.pdf (accessed 10 May, 2020).

Southall, A. (2020, April 17). Why a drop in domestic violence reports might not be a good sign. New York Times. Retrieved from https:/www.nytimes.com/2020/04/17/nyregion/new-york-city-domestic-violencecoronavirus.html (accessed 25 June, 2020).

U.S. Bureau of Labor Statistics (2020, May 8). The employment situation-April 2020. Retrieved from https://www.bls.gov/news.release/empsit.nr0.htm (accessed 10 May, 2020).

U.S. Census Bureau (2016, December 8). New census data shows differences between urban and rural populations. Retrieved from https:/www.census.gov/newsroom/press-releases/2016/cb16-210.html (accessed 10 May, 2020).

U.S. Department of Agriculture (2019). 2013 rural-urban continuum codes [Data set]. Retrieved from https://www.ers.usda.gov/webdocs/DataFiles/53251/ruralurbancodes2013.xls?v=0 (accessed 10 May, 2020).

Vazquez, S. P., Stohr, M. K., \& Purkiss, M. (2005). Intimate partner violence incidence and characteristics: Idaho NIBRS 1995 to 2001 data. Criminal Justice Policy Review, 16(1), 99-114. https://doi.org/10.1177 /0887403404267771.

Weisheit, R. A., Wells, L. E., \& Falcone, D. N. (1994). Community policing in small town and rural America. Crime \& Delinquency, 40(4), 549-567. https://doi.org/10.1177/0011128794040004005.

Weisheit, R. A., Wells, L. E., \& Falcone, D. N. (1995). Crime and policing in rural and small- town America: An overview of the issues. National Institute of Justice. Retrieved from https:/www.ncjrs.gov/pdffiles1 /Digitization/154354NCJRS.pdf (accessed 10 May, 2020).

Weisheit, R. A., Falcone, D. N., \& Wells, L. E. (2006). Crime and policing in rural and small-town America. Prospect Heights, IL: Waveland Press.

Wilson, J. Q. (1968). Varieties of police behavior. Cambridge, MA: Harvard University Press.

Wooff, A. (2015). Relationships and responses: Policing anti-social behaviour in rural Scotland. Journal of Rural Studies, 39, 287-295. https://doi.org/10.1016/j.jrurstud.2014.11.003.

Wooff, A. (2017). 'Soft' policing in rural Scotland. Policing: A Journal of Policy and Practice, 11(2), 123131.

Yarwood, R., \& Cozens, C. (2004). Constable countryside? Police perspectives on rural Britain. In L. Holloway \& M. Kneafsey (Eds.), Geographies of rural cultures and societies (pp. 145-172). London, UK: Routledge.

Publisher's Note Springer Nature remains neutral with regard to jurisdictional claims in published maps and institutional affiliations.

J. Andrew Hansen is an Assistant Professor in the Department of Criminology and Criminal Justice at Western Carolina University. His research interests include policing and conservation. He is currently conducting a study of criminal justice practitioner salaries in rural Western North Carolina counties.

Gabrielle L. Lory is a Doctoral Student in the Department of Sociology and Anthropology at West Virginia University. Her research interests include rural crime and victimology. She currently serves as co-editor of The Rural Criminologist newsletter. 